\title{
Gender and educational background: Influence on entrepreneurial intention (EI) in economics learning
}

\author{
Jun Surjanti', Tony Seno Aji ${ }^{2}$ Zainur Rahman $^{3}$, Heny Musfidah ${ }^{4}$ \\ ${ }_{1,2,3}$ Faculty of Economics, Universitas Negeri Surabaya, Indonesia \\ ${ }^{4}$ Post Graduate Management, Universitas Negeri Surabaya, Indonesia
}

\begin{tabular}{|c|c|}
\hline Article Info & ABSTRACT \\
\hline Article history: & Student behavior is one of important aspects to determine both direction and \\
\hline Received Sep 25, 2019 & $\begin{array}{l}\text { process in the Economic Theory learning. This study aims to draw how those } \\
\text { two factors, gender and educational background, support the emergence and }\end{array}$ \\
\hline Revised Oct 30, 2019 & development of student entrepreneurial intention. This study is a quantitative \\
\hline Accepted Nov 29, 2019 & $\begin{array}{l}\text { study using explanatory survey. Data were analyzed by two-way ANOVA } \\
\text { design to find the relationship/influence of gender and educational }\end{array}$ \\
\hline Keywords: & $\begin{array}{l}\text { background on student entrepreneurial intention. The population was } 111 \\
\text { students. Saturated samples were used as sampling technique. The results }\end{array}$ \\
\hline Educational background & indicate that both gender and educational background had no significant \\
\hline Entrepreneurial intention & influence on student entrepreneurial intention. Therefore, lecturers can \\
\hline Gender & $\begin{array}{l}\text { Theory courses. } \\
\text { Thes a }\end{array}$ \\
\hline Interest-based learning & \\
\hline
\end{tabular}

Copyright $\odot$ 2019Institute of Advanced Engineering and Science. All rights reserved.

\section{Corresponding Author:}

Jun Surjanti,

Faculty of Economics,

Universitas Negeri Surabaya,

Ketintang Street No.2, Ketintang, Kec. Gayungan, Kota Surabaya, Jawa Timur, 60231, Indonesia.

Email:junsurjanti@unesa.ac.id

\section{INTRODUCTION}

Schenkelet al [1] mentioned that organizations and universities should pay attention to human resources as one of the main investments. Universities should map the development of learning tailored to the interests of students in doing business. According to [2], students need sufficient application and information for their career development because without appropriate information, they will meet many difficulties in determining the direction of their goals. Surjanti et al [3] found how interest-based curricula can foster student business interest in the culinary and service fields. However, to achieve the expected results an appropriate learning strategy and design is needed. From student's point of view, learning about entrepreneurship has a high difficulty level, especially in the learning approach and the application of learning strategies [4]. By this reason, to prepare learning strategy and design that can be optimally applied to students, lecturers need to obtain data especially related to factors that likely influence the learning success. In current development, the high level of unemployment is a very common phenomenon found in almost all countries in the world. According to data obtained by the International Monetary Fund, in 2009 alone there were more than 200 million unemployed people or $7 \%$ of the world's population [5]. In 2017, in South Africa, the unemployment rate reaches $26.7 \%$ of the total population and this is still possible to increase [6]. In their research, found that there was a $45 \%$ unemployment rate in the Republic of Kosovo which was one of the sources of economic problems from that country [7]. With these phenomena, an effort to reduce or overcome the unemployment rate needs to be done as soon and as thoroughly as possible [8].

According to [9], one of the factors causing the high unemployment rate is the population. Population is an important factor to develop the national economy. This population includes the labors (employees) and business actors. Of the two functions, the population as business actors will be very helpful 
in decreasing the unemployment rate. As stated by [10], promoting entrepreneurial spirit can create new business actors. Nonetheless, this also raises another concern where new business actors must be faced with several internal and external constraints [11]. Internal constraints include lack of creativity, limited capital, lack of socialization, uncertainty in income, fear of risk (wanting to be in a safe zone), lack of confidence in leadership, dislike of challenges, and impatience in starting a business from the start. While external constraints such as the notion of low purchasing power, lack of support from family and environment, lack of network, difficulties in attracting customers, lack of funding, lack of education system support, lack of opportunities, and lack of social prestige (where most parents want children become employees) . One of various ways to promote entrepreneurial intention is by incorporating it into education system, especially in higher education, because higher education is the first level of higher education to produce professional staff [12]. By subjecting entrepreneurial intention in the learning curriculum in higher education will reduce internal and external factors from the creation of business actors.

An entrepreneurial intention will be influenced by various factors in its growth. Study conducted by [13] found that entrepreneurial intention is influenced by entrepreneurial urges that emerged from the region, social support, as well as strategic entrepreneurial mastery. According to [14], there are five factors that influence students in determining interest, including preferences, environmental influences, marketing specialties, gender, and career guarantees. In addition, students' knowledge of future career is one of the factors to consider in determining a career. Moreover, the level of social class, financial resources, affordability, and future working skill will also influence career choices [15]. From several studies, gender and educational background can be factors that influence the emergence of entrepreneurial intention [16]. Referring to this opinion, this study expects to relate whether gender and student educational background possibly influence the growth of student entrepreneurial intention, especially in Economic Theory learning.

Gender is a quite sensitive and popular issue to study. Therefore, this study wishes to know how gender involves in developing student entrepreneurial intention in Economic Theory learning. Osakede, et-al [17] found that in Nigeria, entrepreneurial involvement was relatively low among students with significant differences across gender. According to [18], in Sweden, women shall be involved in business to survive and to maintain their status and emancipation. Regarding gender issues, this study analyzes how gender influence on the learning of economic theory based on entrepreneurial intention.

Students in higher education institutions come from different regions and backgrounds, which of course, resulting in differences of their educational background. At Universitas Negeri Surabaya, especially in the management department, Faculty of Economics, students came from a various educational backgrounds, not only from location but also from prior education/knowledge [such as: Senior High School (majoring both science and social) and Vocational Senior High School]. To address these differences, various opinions and perceptions emerged especially in how to treat these students in the learning activity. According to [19] educational background has insignificant influence in increasing the intention of business student entrepreneurs. However, this contrasts with the results of previous studies that confirm the existence of a positive relationship between educational and entrepreneurial backgrounds [20]. Therefore, the influence of educational background on entrepreneurial intention remains doubtful. Addressing these conditions, a supporting program proposing to increase the entrepreneurial intention is necessary to be carried out not only by the government but also higher education institutions as formal education.

Considering to prior studies as well as observations, this study analyzes whether both gender and student educational background significantly influence student entrepreneurial intention or not. The results of this study will be used as a database to develop and prepare learning design and strategies for Economic Theory. In addition, this study can also serve as reference in designing a new curriculum that answers the challenges of the need for entrepreneurial intention in the education.

\section{LITERATURE REVIEW}

\subsection{Entrepreneurial intentions}

Entrepreneurship has been considered as one of the drivers of economic growth and changes. In current economic environment where employment is scarce, many students prefer entrepreneurship as career choices to employment. Entrepreneurial activity can be understood as the ability of humans to form environmental conditions that benefit them through a visionary process to create reality [13]. In addition, Costa argues that entrepreneurial intentions are an intention in how to carry out entrepreneurial activities that are closely related to human interests and their future visionaries. Meanwhile aspects of human behavior are important to develop entrepreneurship [21]. Wulandari [22] stated that entrepreneurial intention is the desire, interest, and willingness to work hard or be strong-willed to optimally bid in meeting their needs without feeling afraid of the risks, and willing to learn from the failures. In connection with student entrepreneurial 
intention, [10] stated the importance of studies on how young people view entrepreneurship as well as their intention on it, so further action can be prepared in order to answer the condition.

\subsection{Gender}

Osakede, et-al [17] explained that subjective norms, such as behavioral control and family entrepreneurship background, significantly foresee student entrepreneurial intentions. However, their engagement in entrepreneurial activities does not guarantee to significantly influence student academic performance. Furthermore, Osakede found that gender does not significantly influence student entrepreneurial intention as well as their academic performance. In Turkey, [23] found that male and female are differently valued; however, although they are valued differently, each value is viewed using different categories, such as strength (men) and tenderness (women). While [24] stated that the importance of gender databases is to divide work/task as it refers to their physical distinctiveness; yet, it does not mean that gender will hinder the task division according to their individual capability. This study aims to create a database for students, especially in Economic Theory class. This database serves to assist lecturers in preparing the learning strategies and design before class activity which proposing on the development and growth of student entrepreneurial intentions

\subsection{Educational background}

In educational process, [25] argued that the modernization of the Westerners over the past two centuries has mixed industrialization and urbanization, without underestimating the traditional views; moreover, it raises the sociological reviews as the ideals of higher education. Educational background allows each individual to have a different culture and mindset. Besides, cultural factors influence the formation of competencies between student cultures [26]. In addition, [27] mention three factors that influence individual entrepreneurial intentions, namely gender, family business experience, and education level. Among them, educational background becomes less significant in influencing individual interests because according to them, knowledge and ownership of information are more significant than the level of education.

\section{RESEARCH METHOD}

This study is a causality research using quantitative with explanatory research - survey approach. Two-way ANOVA design was employed to determine the relationship/influence of the independent variables (gender and educational background) to the dependent variable (entrepreneurial intentions). The population was management students of 2018 academic year who programmed micro-Economic Theory. There were 111 sampling taken using saturated sample method.

\section{RESULTS AND DISCUSSION}

The data for this study was from nominal data of 76 male students (68\%), 35 females (32\%). The student educational background was 33 students from Senior High School majoring Science (29\%), 69 students from Senior High School majoring Social Science (63\%), and 9 students from Vocational High School (8\%). To test the hypotheses, the researchers employed a two-way ANOVA analysis. Prior of ANOVA testing, data were tested for their homogeneity as it is required in Two-Way ANOVA that one of variables has to be homogeneous. Lavene test using SPSS 21.0 for Windows was used for the homogeneity

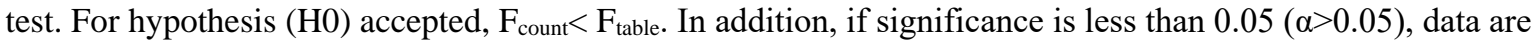
homogeneous. In contrary, if significance is higher than $0.05(\alpha<0.05)$, data are heterogeneous. Table 1 shows the results of the homogeneity test using the Levene's test using SPSS 21.0 for Windows Program.

Tabel 1. Levene's test of equalityof error variances ${ }^{\mathrm{a}}$

\begin{tabular}{|c|c|c|c|}
\hline \multicolumn{4}{|c|}{ Dependent Variable: Y1.1 } \\
\hline $\mathrm{F}$ & df1 & df2 & $\alpha$. \\
\hline 1.505 & 3 & 107 & .218 \\
\hline
\end{tabular}

Table 1 shows the homogeneity test using Levene test. If the Significance $(\alpha)$ is more than $0.05(>$ $0.05)$ the data consider as homogeny. Table 1 shows that the significance value is 0.22 or higher than 0.05 , 
meaning that the data is homogeny. To test the hypotheses, researchers employed the two-ways ANOVA using SPSS 21.0 for Windows.

Table 2 shows the scores from the two-way ANOVA test. It is explained as Corrected Model shows the effect of gender and educational background (independent variables) as well as how both variables interact with entrepreneurial intention (dependent variable). If the Significance $(\alpha)$ is less than 0.05 , it means there is significant influence. In addition, the two-way ANOVA also shows the intercept. Here explains that there is a changing value in dependent variable (entrepreneurial intentions). However, this changing was not influenced by any independent variable meaning that independent variables have no significant influence on dependent variable (entrepreneurial intention) as it remains change with or without the interference of independent variables (gender and educational background). It shows by the value of Significance $(\alpha)$ less than $0.05(\alpha<0.05)$. Thus, if Significance $(\alpha)$ of the Intercept is 0.000 meaning that the Intercept is significance. The last is R Squared. The analysis finds that the value of multiple determinations on dependent variable to independent variables. Result shows that $R$ square is 0.29 meaning that independent variables influence the dependent variable by $29 \%$. Meanwhile the remaining percentage is due to other variables outside the model.

Table 2. Tests of between-subjects effects

\begin{tabular}{lccccc}
\hline \multicolumn{1}{c}{ Source } & \multicolumn{2}{c}{ Dependent Variable: Y1.1 } & & \\
\hline Corrected Model & $4.071^{\mathrm{a}}$ & 3 & 1.357 & 1.074 & .364 \\
Intercept & 1126.078 & 1 & 1126.078 & 891.025 & .000 \\
X1 & 3.199 & 1 & 3.199 & 2.531 & .115 \\
X2 & .844 & 1 & .844 & .668 & .416 \\
X1 $*$ X2 & .292 & 1 & .292 & .231 & .631 \\
Error & 135.227 & 107 & 1.264 & & \\
Total & 1617.000 & 111 & & & \\
Corrected Total & 139.297 & 110 & & & \\
\hline
\end{tabular}

a. R Squared $=.029$ (Adjusted R Squared $=, 002$ )

Hypothesis 1 shows the $F_{\text {count }}$ as 2.531 with Significance $(\alpha)$ of 0.115 meaning that there is no influence of gender on entrepreneurial intentions. While hypothesis 2 shows the $F_{\text {count }}$ as 0.668 with significance $(\alpha)$ of 0.416 meaning that there is no influence of educational background (students' prior education/graduate) on entrepreneurial intentions (see Table 2). Data show that student entrepreneurial intentions were not influenced by neither gender nor educational background of students. It means that both male and female students have same opportunity to be entrepreneurs. In addition, specific major taken on prior education (e.g. science or social majoring) did not determine the students entrepreneurial intentions, in other words, any major serve same opportunity.

The result indicates that lecturers of Economic Theory do not necessarily distinguish gender while conducting learning activities. This is in line with [17] research in Nigeria, in which gender did not make a significant difference in the growth of student entrepreneurial intentions and learning abilities. Similarly, in another research on gender, gender distinction is only needed to allocate the work/task fairly as physically both have distinctive features [24]. In Turkey, research on gender and education found that women and men had different scores in certain respects [23]. Thus, this result can serve as database to assist lectures in determining the appropriate strategies and designs for Economic Theory learning in order to develop and grow student entrepreneurial intention

\section{CONCLUSION}

Based on data analysis, it was found that both gender and educational background did not influence on the development of student entrepreneurial intention. This indicates that in preparing strategies and designs for Economic Theory class, lecturers are not obliged to provide special treatment referring to them (gender and educational background). Although, there are indeed particular business types that are preferred by certain students. Yet, these did not relate to both gender and educational background (their influence in learning activities), it mainly related to individual interest. However, the emergence of these different entrepreneurial intentions at the end of learning and their causes are not discussed in this study. Therefore, the result of this study can be used as a basis for further research. 


\section{ACKNOWLEDGEMENTS}

This study was PNBP research funded by SKIM PNBP UNESA through LPPM Universitas Negeri Surabaya. Thus, greatest gratitude was delivered to all related parties, especially the rector of Universitas Negeri Surabaya as well as the Head of LPPM Universitas Negeri Surabaya.

\section{REFERENCES}

[1] Schenkel, M. T., Brazeal, D. V, and Azriel, J. A. "Pathways in the development of entrepreneurial intent : exploring the roles of prior experience, sex, and family business background," Journal of Business \& Entrepreneurship, pp. 47-69, 2013.

[2] Üzüm, P. A. "Opinions of students' about talent management at Universities, "International Online Journal of Educational Sciences, vol. 9(2), pp. 464-485.2017.

[3] Surjanti.J, Nugrohoseno.D, Budiono and Musfidah.H. "The implementation of interest-based entrepreneurship curriculum in the Theory of Economics course," In IOP Conference Series: Materials Science and Engineering PAPER, pp. 1-6, 2018.

[4] Lackéus, M. Entrepreneur in Education. What, Why, When, How, OECD,2015

[5] Öner, Ceyda."Unemployment: The curse of joblessness, finance \& development. International monetary fund. Published December 18," 2018. https://www.imf.org/external/pubs/ft/fandd/basics/unemploy.htm

[6] Du Toit, M., De Witte, H., Rothmann, S, and Van den Broeck, A, "Contextual factors and the experience of unemployment: A review of qualitative studies," South African Journal of Economic and Management Sciences, vol. 21(1), 2018.

[7] Ukaj, Mic and Dragusha, Blerim, "Unemployment and labour force market in Republic of Kosova," International Journal of Business and Social Research (IJBSR), vol. 3(2), Feb 2013. [Online] Available: https://thejournalofbusiness.org/index.php/site/article/download/80/79.

[8] Castro, M. C. De. "Spatial demography: an opportunity to improve policy making at diverse decision levels," pp. 477-509, 2007

[9] Puspadjuita, Erna. "Factors that Influence the rate of unemployment in Indonesia," International Journal of Economics and Finance, vol. 10(1), 2018. http://www.ccsenet.org/journal/index.php/ijef/article/view/72364. doi:10.5539/ijef.v10n1p140.

[10] Maryani, Pentiana, D and Wijaya, L. R. P. "Identification and evaluation of the interest of college students in becoming entrepreneurs," Academy of Entrepreneurship Journa, vol. 24(3), pp. 1-8.2018.

[11] Murphy, P. J., Liao, J, and Welsch, H. P. 2006. "A conceptual history of entrepreneurial thought," Journal of Management History, vol. 12(1), pp. 12-35, 2006.

[12] Schmitt, C and Husson, J. "Entrepreneurial situations, definition and interests for entrepreneurial research," vol. 1(Jan), 2017.

[13] Costa, Francisco José, Soares, A. A. Cavalcante, and Bonfim, D. Guilherme. "Factors of influence on the entrepreneurial interest: an analysis with students of information technology related courses," Journal of Information Systems and Technology Management, vol. 6(2), pp. 227-246, 2009.

[14] Al-Lawati, E. Hussain, Kumar. R, and Subramaniam, Radhakrishnan. "An empirical study on factors influencing business students' choice of specialization with reference to nizwa college of technology," International Business Research, vol. 10(9), Oman, 2017.

[15] Afaq Ahmed, K., Sharif, Nimra, and Ahmad, Nawaz. "Factors influencing students' career choices: empirical evidence from business students,"Journal of Southeast Asian Research, pp. 1-15, 2017.

[16] Alsaaty, Falih M., Abrahams, David, and Carter, Ella. "Business students' interests in entrepreneurship and social entrepreneurship at a historically black institution," Journal of Small Business and Entrepreneurship Development, vol, 2(1), pp. 01-30, Mar 2014. [Online] Available:http://jsbednet.com/journals/jsbed/Vol_2_No_1_March_2014/1.

[17] Osakede, U. A., Lawanson, A. O, \& Sobowale, D. A. "Entrepreneurial interest and academic performance in Nigeria: evidence from undergraduate students in the University of Ibadan," Journal of Innovation and Entrepreneurship, 2017. http://doi.org/10.1186/s13731-017-0079-7

[18] Ericsson, T and Ericsson, T. "Women, family, and small business in late nineteenth century Sweden," vol. 5398(1), 2012.

[19] Nguyen, C. J. "Demographic factors, family background and prior self-employment on entrepreneurial intentionVietnamese business students are different: why?," Journal of Global Entrepreneurship Research, 2018.

[20] Van der Sluis, Justin \& Praag, Mirjam \& Vijverberg, and Wim. "Education and entrepreneurship in industrialized countries: a meta-analysis," World Bank Economic Review, 2004.

[21] Filion, L. J. "Defining the entrepreneur complexity and multi-dimensional systems some reflections author: Louis Jacques filion working paper," pp. 840-853, 2008.

[22] Aji, A. D., Sofyandi, H, and Tarmidi, D. "The effect of self-efficacy, creativity, and motivation on entrepreneurship interest in FBM students of widyatama university," Indonesia. Global Business and Management Research: An International Journal, vol, 11(1), pp. 87-96, 2019.

[23] Dirilen-gumus, O and Buyuksahin-sunal, A."Gender differences in Turkish undergraduate students' values," pp. 559-570, 2012.

[24] Martin, L. M., Warren-smith, I., Adams, H., Scott, J. M, and Roper, S. "Boards of directors and gender diversity in UK companies," 2008. http://doi.org/10.1108/17542410810866944

[25] Veen, R. Van Der. "Demography, social structure, and learning through life," 2010

Int. J. Eval.\& Res. Educ.Vol. 8, No. 4, December 2019: 604-609 
[26] Malazonia, D., Maglakelidze, S., Chiabrishvili, N, and Gakheladze, G. "Factors of students' intercultural competence development in the context of Georgia," Cogent Education, vol. 12(1), pp. 1-17. 2017. http://doi.org/10.1080/2331186X.2017.1302867

[27] Wang, Clement K and Wong, Poh-Kam. "Entrepreneurial interest of university students in Singapore," Technovation, pp. 163-172, 2004. [Online] Available: https://www.journals.elsevier.com/technovation.

\section{BIOGRAPHIES OF AUTHORS}

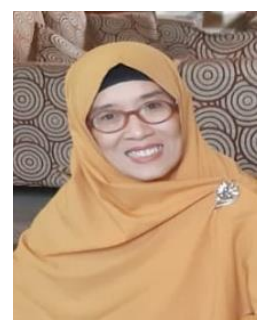

Jun Surjanti is a lecturer in Department of Management, Economics Faculty Universitas Negeri Surabaya. She was born in Yogyakarta in 1967. She got Bachelor's Degree on Economics Education from Universitas Negeri Surabaya in 1992 and continued her graduate program in Airlangga University when she graduated in 2000 for her Master's Degree in Management. In 2012 she got her Doctor's Degree on Economics Education from Universitas Negeri Malang. She is a passionate person. She is an active lecturer in Department of Management, Economics Faculty Universitas Negeri Surabaya. She has published articles both national and international journal, seminars and proceeding. Mostly her writing focus is in economic and management education, especially in learning behaviors. Her published articles relating to these were coastal and marine-based learning behavior, mangrove-based learning, entrepreneur behavior and individual orientation entrepreneur, as well as the mobile use learning behavior. Apart from journal, she also wrote books; some of her books are Introduction to Economics, Economics Theory, and Character-based Economics. She was invited to be keynoter on academic seminars, workshops, and open-lecturing.

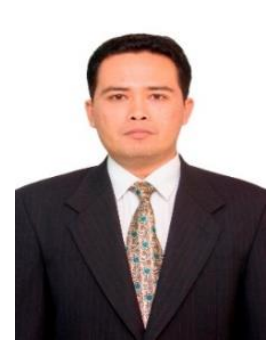

Dr. Tony Seno Aji, S.E., M.E. born in Magelang, on September 24, 1978. In 2001 completed his Bachelor of Economics and Development Studies at Jenderal Soedirman University, Purwokerto. In 2008, he graduated with a Masters in Economics from University of Brawijaya, Malang. A doctorate degree was obtained after completing a study in the Doctor of Economics program at University of Brawijaya in 2016.

The author is also active writing in several journals, both nationally and internationally. Among them are the Journal of Applied Economic Sciences (JAES), Journal of Applied Economics and Business (JAEB), International Journal of Academic Research in Business and Social Affairs, Information Management and Business Review, Journal of Development Economics, Journal of Civil Society Empowerment, J-Dynamics. Some journals are DIKTI accredited, indexed by SCOPUS, COPERNICUS, EBSCO, rePEc, CEEOL, DOAJ, ULRICHS, JournalITOCs, EZB. While books that have been published by authors include; Dasar-Dasar Ekonomi Moneter (2010), Transformasi Paradigma Pembangunan Ekonomi (2014).

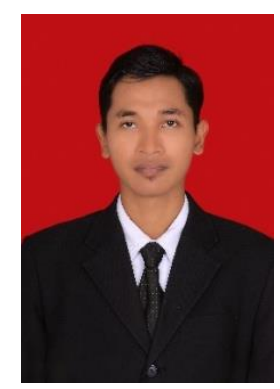

Zainur Rahman, born March22, 1991, received his Bachelor of Management from the Faculty of Economics and Business, Universitas Negeri Surabaya, then he continued their master degree in Management Program, Faculty of Economics and Business, Universitas Gadjah Mada, Yogyakarta. Currently he is a lecture of Mangement Program at the Universitas Negeri Surabaya, Indonesia. Research focus on the field of Human Resource Management, Organizational Behavior, and Organizational Change. He has published his article injournal and proceeding: 1) Food Industry Performance: Entrepreneurial Leadership And Human Capital Perspective; 2) Does Organizational Culture Matters inOrganizational Change?Transformational Leadership and CynicismAbout Organizational Change. Beside, hejoined to be speaker on academic seminars and workshops.

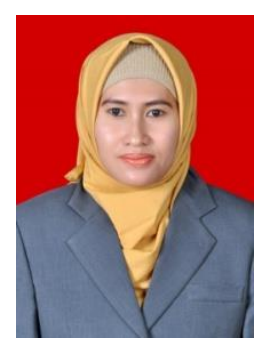

Heny Musfidah is a student in Postgraduate Program, Economics Faculty Universitas Negeri Surabaya. She was born in Mojokerto 1985. She got Bachelor's Degree on Economics Education from Universitas Negeri Surabaya in 1998 and continued her graduate program in Economic Education, Universitas Negeri Malang in 2012 - 2014. Now, she is student in CPD for Management Program, Universitas Negeri Surabaya. With doing activities as student, she also do research actively in CV Mitra Karsa Utama - a research and management consultant in Surabaya, Indonesia. 